41 | 2010

Le cheval : monture, nourriture et figure

\title{
Riding horse tack among the cattle-breeders of Central Asia and Southern Siberia in the first and second millennia $\mathrm{CE}$
}

Irina Dmitrievna Tkačenko

\section{(2) OpenEdition \\ Journals}

Electronic version

URL: https://journals.openedition.org/emscat/1552

DOI: 10.4000/emscat.1552

ISSN: 2101-0013

Publisher

Centre d'Etudes Mongoles \& Sibériennes / École Pratique des Hautes Études

Electronic reference

Irina Dmitrievna Tkačenko, "Riding horse tack among the cattle-breeders of Central Asia and Southern Siberia in the first and second millennia CE", Études mongoles et sibériennes, centrasiatiques et tibétaines [Online], 41 | 2010, Online since 15 April 2010, connection on 13 July 2021. URL: http:// journals.openedition.org/emscat/1552 ; DOI: https://doi.org/10.4000/emscat.1552

This text was automatically generated on 13 July 2021.

(c) Tous droits réservés 


\title{
Riding horse tack among the cattle- breeders of Central Asia and Southern Siberia in the first and second millennia $\mathrm{CE}$
}

\author{
Irina Dmitrievna Tkačenko
}

\section{AUTHOR'S NOTE}

The present article is based on the materials collected and analyzed in the author's dissertation (Tkačenko, 2009)

\section{Introduction}

1 The formative period of the economic and cultural aspects of nomadic cattle-breeders in the area of the Eurasian Steppe began in the middle of the first millennium BCE (the so-called Scythian epoch) and ended in the middle of the first millennium CE (the old Turkic epoch). The particular place of horses in nomadic culture was determined by their role in the nomads' economic activities. The use of horses as pack and riding animals made it possible to migrate and control large amounts of livestock. The invention of horse riding per se and its consequent technical improvements (such as the invention and development of a saddle with a firm wooden tree and stirrups) afforded new opportunities (first of all in a military context) and changed the tactics of warfare to a great extent. The role of horse meat, milk, hides and hair was also significant.

2 The nomads of the Scythian epoch used the so-called "soft saddle" for riding, which consisted of two leather pads stuffed with hair or grass. This construction is well known from the finds of the famous Pazyryk burials of the fifth to third centuries BCE, where the organic remains such as wood, leather and textiles as well as human and 
horse mummies were preserved in the permafrost. In the early part of the first millennium CE the first saddles with firm wooden trees and stirrups started to appear in the area of Xiongnu and Xianbei confederations in the Northern part of Central Asia. These inventions led to a real technical revolution, particularly for military purposes. This was the beginning of a new archaeological epoch with the domination of the old Turks on the historical stage.

3 The events that took place between the sixth and eleventh centuries in Southern and South-Eastern Siberia (Altai, the Minusinsk Depression, Tuva, Northern Mongolia and the eastern shores of Lake Baikal) set the stage for a new cultural model which developed continuously for many generations thereafter. This was a period of constant warfare when numerous multi-ethnic state formations replaced one another (Savinov 1984, p. 3). The creative energy of the population was focused on the modernization of those aspects of their life that were immediately connected with military affairs. That is the reason why the progressive inventions in the fields of horse and military equipment spread so rapidly across a wide territory.

4 In the ethnographic period ${ }^{1}$ the important role of the riding horse in traditional nomadic culture remained intact. The study of horse tack in a wide chronological range (from the middle of the first millennium CE until the twentieth and twenty-first centuries) allows a scholar to distinguish transtemporal types, where some elements have been preserved until nowadays while their sources date back to the early medieval period and sometimes even to the Scythian epoch ${ }^{2}$.

\section{The principles of saddle typology}

5 Although academic literature widely uses the term saddle type there has been no general typology formulated so far. Usually, these types are pinpointed with reference to limited and mostly local data, and it is difficult to combine them within a wider territorial and chronological framework. The examination of nineteenth and twentieth century ethnographic material allows us to distinguish four provisional saddle types, which differ principally in the construction of the wooden tree. The first two are basic types and the latter two are derived from them. 

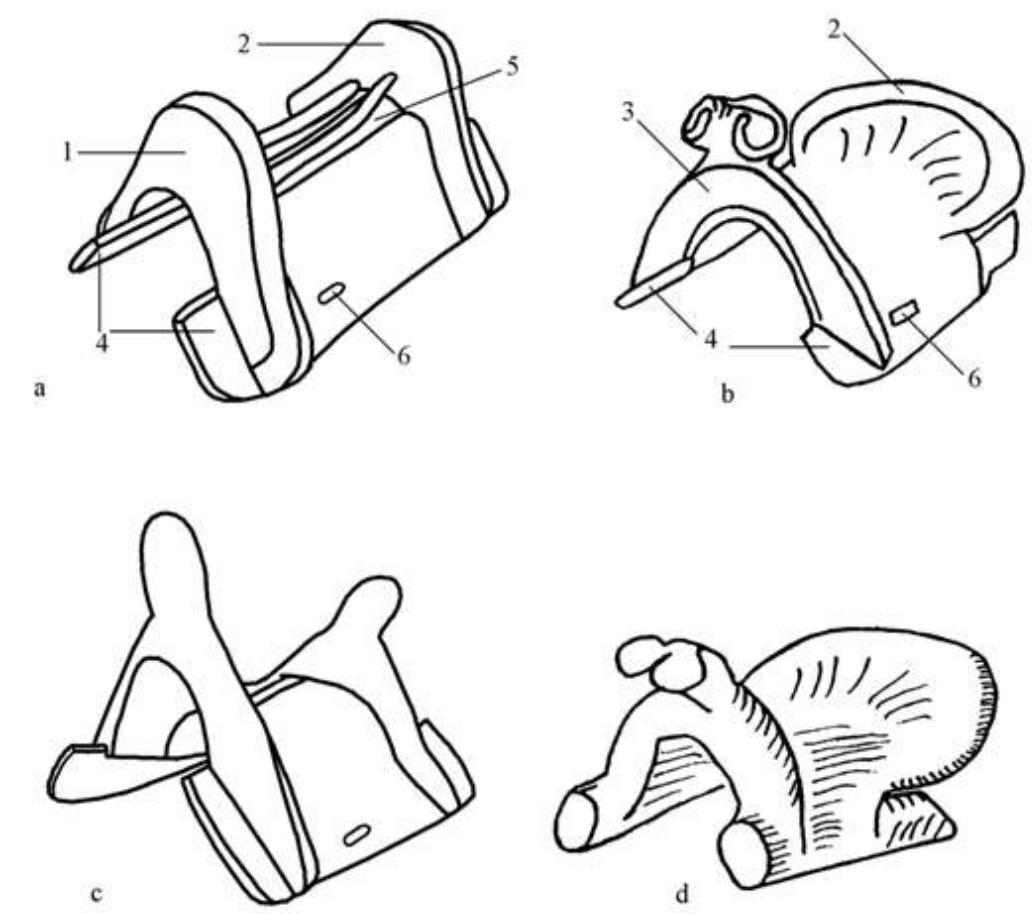

a - saddle with a compound tree (I type)

b - saddle with a multipartite compound tree (I type)

c - saddle with a compound tree and a figured pommel (III type)

$\mathrm{d}$ - saddle with a solid tree (iv type)

1 - front arch; 2 - rear arch; 3 - figured pommel; 4 - bar; 5 - vacuity between bars; 6 - aperture for the stirrup leather

6 I. Saddle with a compound tree consists of four wooden parts (two side-bars and two arches) with semicircular, orthogonal or triangular arches. It was universally made of birch-wood. As one can see from the analysis of the archaeological finds (see below), its origins and development are connected with the nomadic cultures of the Far East, the northern part of Central Asia and Southern Siberia. It is conventionally called the Southern Siberian Type (diagram 1: a).

II. Saddle with a multipartite compound tree with more than 30 tiny details made of willow with a slender front arch, which culminates with a figured pommel, and a semicircular rear arch. Its origins and evolution have not been traced back, but it probably originated in the cultural tradition of settled peoples. The main centers of the production of such saddles in Central Asia in the second part of the nineteenth century were Tashkent and Samarkand, which rivaled one another. From these centers these saddles spread over the whole of the Turkestan Krai and even beyond its borders. Since the main craftsmen engaged in the production of such saddles were Sarts (the settled population of Central Asia), this type may be called the Sartic type. This saddle is also called the Bukharan or Andijan saddle (diagram 1: b).

III. Saddle with a compound tree made of four parts where the slender front arch culminates in a figured pommel, or with two arches with protrusions in their curves. These saddles are widespread in the Caucasus and Kazakhstan (diagram 1: c). 
IV. Saddle with a solid tree made of one piece of wood (usually birch). Its shape is similar to the Sartic saddle with the front arch furnished with a pommel. Such saddles are known among the Bashkirs and the Kyrgyz (diagram 1: d).

This classification does not include the so-called Cossack or cavalry saddle, with arches made of curved metallic tubing, and which are nowadays widely used in Siberia and Central Asia, saddles of knights of medieval Western Europe, Western saddles, American Indian saddles, modern racing and sport saddles etc. In the present article we examine the history of the development of the first type, the Southern Siberian saddle. Our main attention is focused on the construction of the saddle tree because the saddle is the fundamental element of horse equipment.

The material of this work is based on the author's field studies (Khakassia, Tuva, 2005; The Altai Highlands, 2006, 2007) as well as her research in the collections of the Russian Ethnographic Museum (St. Petersburg), the Museum of Anthropology and Ethnography named after Peter the Great of the Russian Academy of Sciences (Kunstkamera, St. Petersburg) and several regional museums in Siberia (Barnaul, Bijsk, Gorno-Altajsk, Minusinsk, Kyzyl, Abakan). The author is grateful to the authorities and staff of these museums for kind allowance to study and use the collections. We should note that the main principle of forming the collections of ethnographic museums and many local museums in Russia and the Soviet Union was to collect mainly everyday items which were in use in traditional people's cultures. These items are the main subject of the present work. The luxurious and elaborately decorative pieces which throw light on the life of the upper classes or the imperial family and are examples per se of artistic creativity are stored and exhibited in art museums such as the Armory Chamber of the Moscow Kremlin or the State Hermitage in St. Petersburg.

\section{Horse equipment of the Early Middle Ages}

12 The question of the origin of the saddle with a firm wooden tree still remains to a large extent controversial. It most likely appeared as a result of contact between sedentary and nomadic peoples in the very beginning of the first millennium $\mathrm{CE}$ in the vast region between the Pamirs and Tibet on the one side and Mongolia and the Far East on the other. The clearest early testimonies on it are related to the Koguryŏ State which existed in Northern Korea and Eastern Manchuria from the first to the seventh centuries CE and so it is called the Koguryŏ saddle in academic literature (Vajnštejn \& Krjukov 1984, p. 114-130; Džarylgasinova 1972, p. 112; Krjukov \& al. 1984, p. 163). 


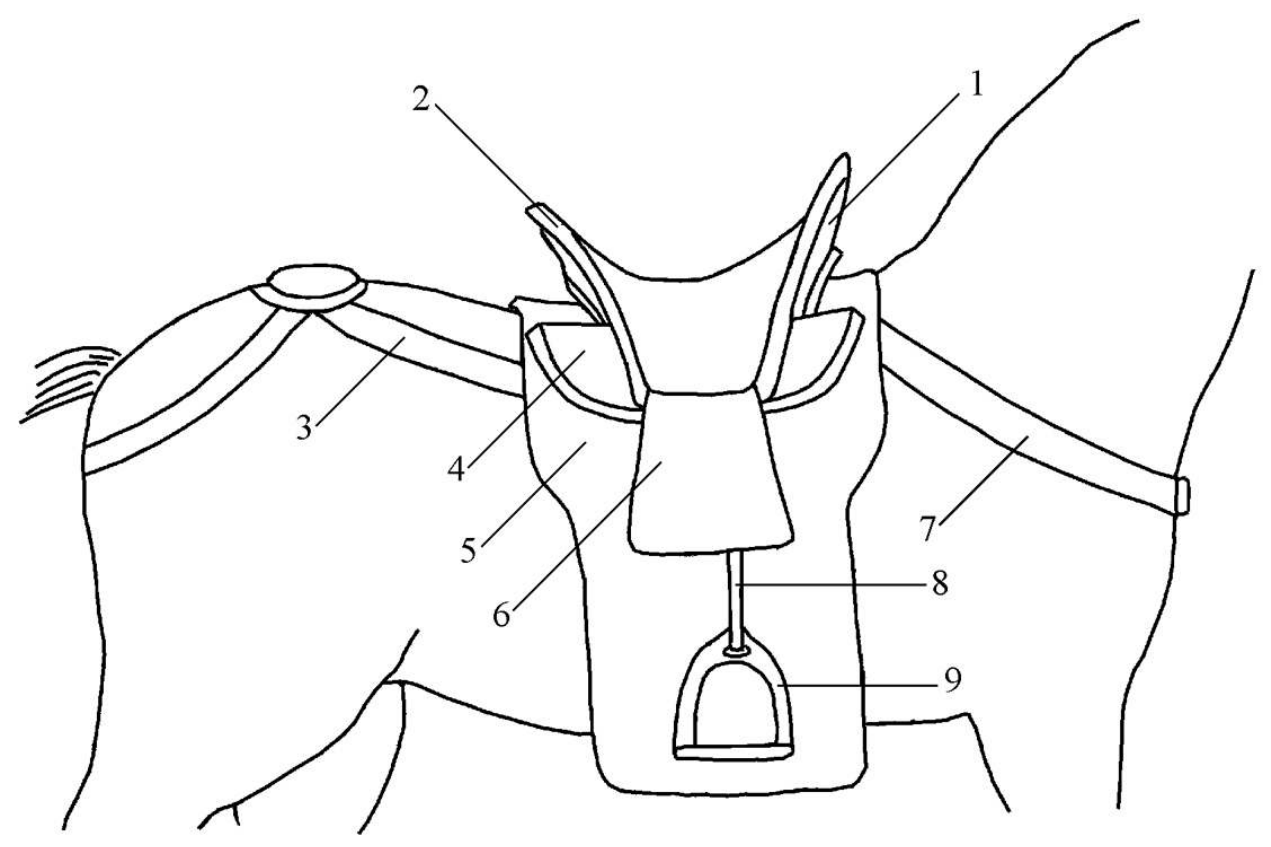

1 - front arch; 2 - rear arch; 3 - crupper; 4 - bar; 5 - blanket; 6 - flap; 7 - breastplate; 8 - stirrup leather; 9 - stirrup

It consisted of two straight bars and two high, upright orthogonal arches (diagram 2; fig. 1: 2). The upper parts of the bars were immediately adjacent to one another forming the seat, and their connection with the arches was firm and immovable. This construction hindered the rider's movements but gave him support while riding, which was very important for heavy armored cavalry.

This saddle was used with iron stirrups. The shape of the earliest stirrups consisted of a round body and a high plaque above it with an aperture for the stirrup leather. The stirrups were attached to the lower ends of the front arch. Consequently the saddle leather did not pass beneath the rider's thigh and the saddle equipment was devoid of flaps (diagram 2: 6), i.e. the special protective leather pad serving to prevent rubbing between the rider's leg and the saddle leather. To prevent the horse's body being hurt by the stirrups, two oblong orthogonal blankets were placed on either side of the animal's body (diagram 2: 5; fig. 1: 1). Two horizontal straps going around the horse's breast (breastplate) and tail (crupper) were attached to the saddle in order to stop it slipping (diagram 2: 3, 7; fig. 1). Most probably the saddle was covered with a saddle pad, but it is difficult to trace it given the extant representations. 

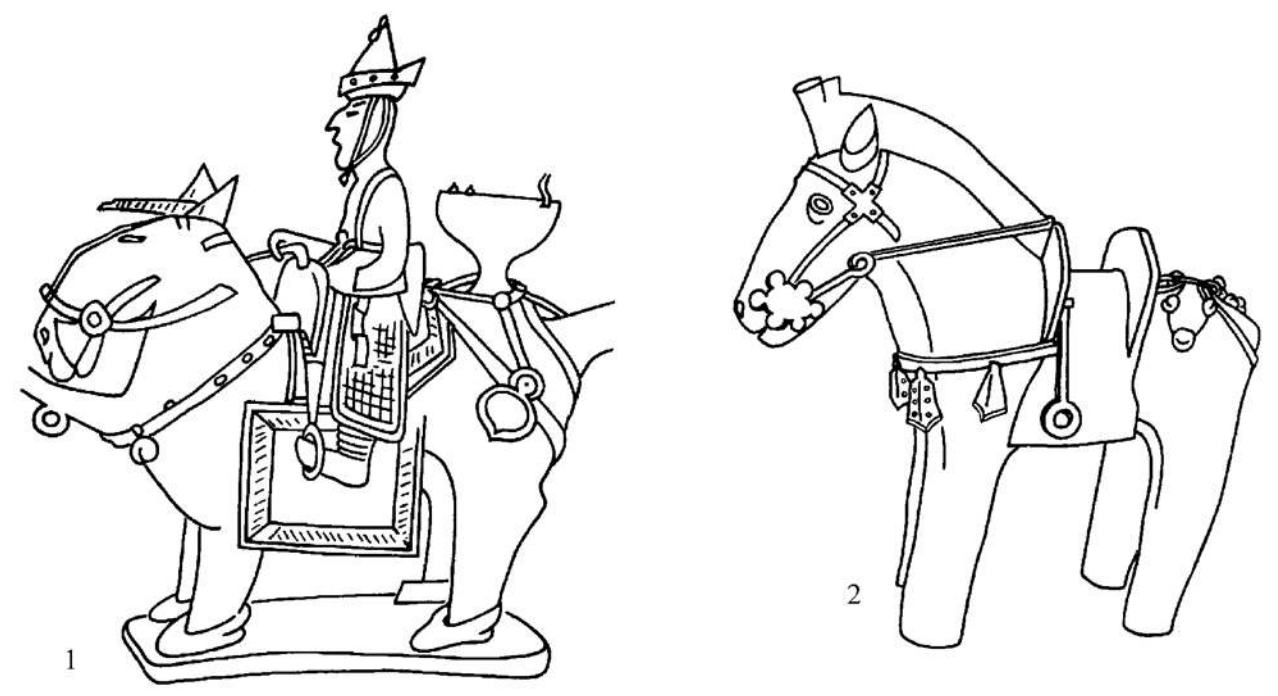

1 - a vessel in the shape of a rider. Northern Korea. $5^{\text {th }}$-6th century

2 - funerary figurine. Japan. $7^{\text {th }}$ century

Vajnštejn 1991

15 The wooden saddle and stirrups widened the agility of the heavily-equipped rider, while the armature of the horse and its rider afforded them a considerable advantage in battle. The old Turks adopted these inventions in the early period of their history and thus furthered their spread over Eurasia.

The idea of making a saddle completely out of wood and using stirrups came to the Altai with the old Turks and it was here, among the nomadic cattle-breeders of this mountain and steppe region, that new technological breakthroughs took place.

Stirrups with the aperture for the leather in the shape of a loop appeared in Southern Siberia (fig. 2: 2); it was an easier and probably less prestigious variant of the Far Eastern prototype with the aperture in the shape of a high plaque (fig. 2:1).

Fig. 2. Stirrups 


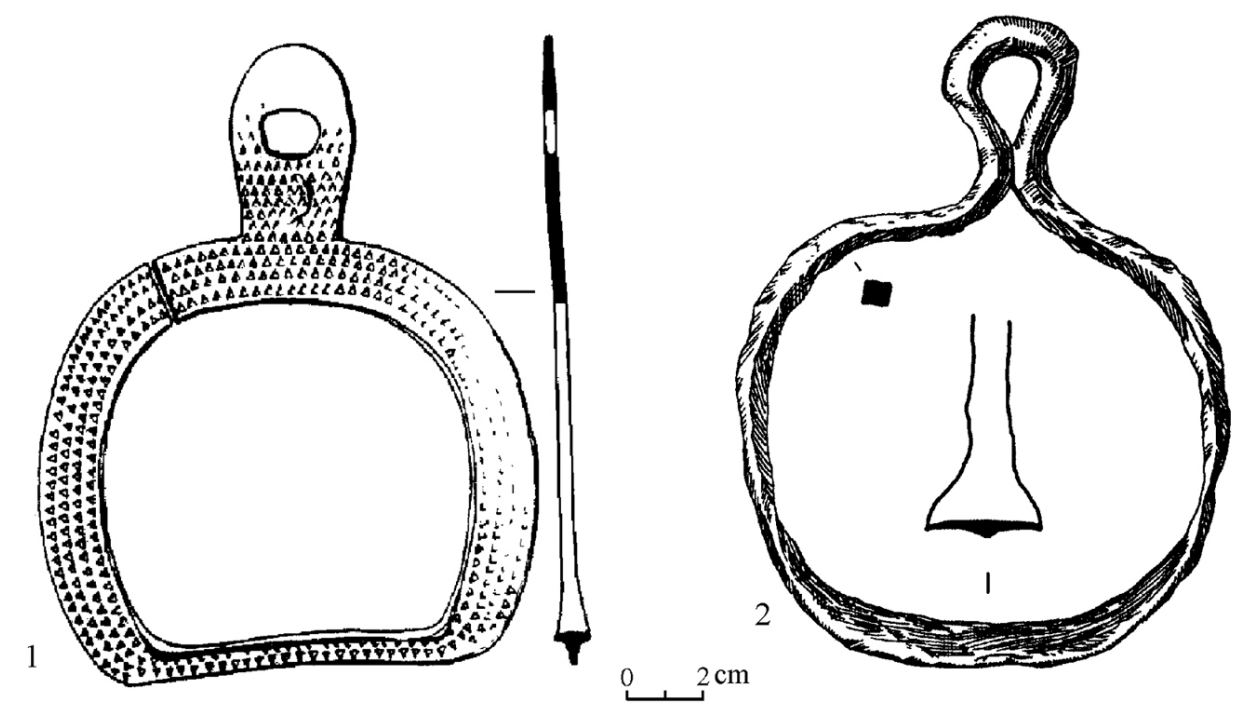

1 - with an eyelet in the shape of a plaque. Ulug-Horum, burial 1. Tuva Grač 1982

2 - with an eyelet in the shape of a loop. Kudyrge, tomb 11. The Altai Highlands Gavrilova 1965

19 The earliest example of the saddle which is called Old Turkic (Vajnštejn 1966, p. 68; Krjukov \& al. 1984, p. 164) was also found here, in the Altai Highlands, in the Yaloman II burial ground (excavations of the Altai State University of Barnaul led by Prof. A. A. Tiškin, 2005-2006).

Fig. 3. The Old Turkic saddle
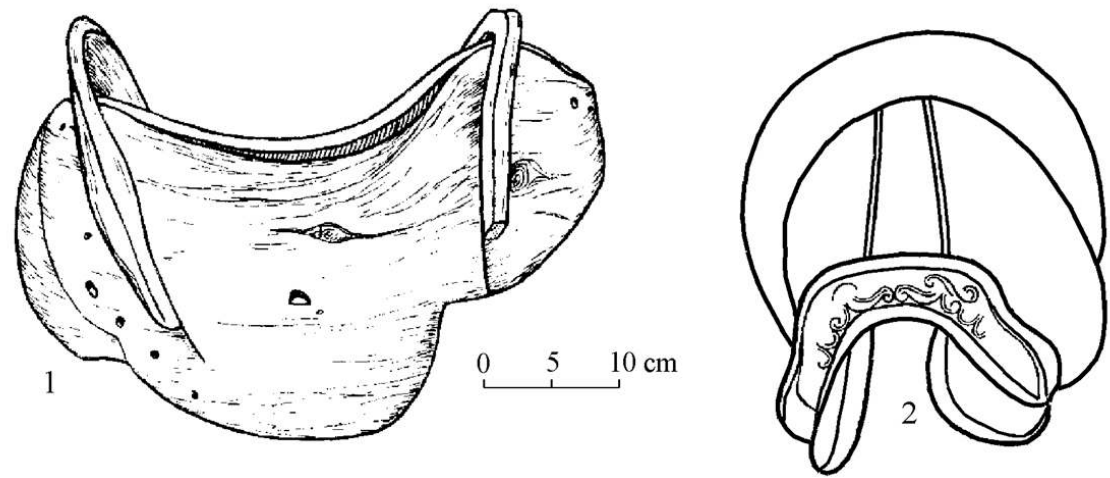

1 - Džolin III, barrow 2. The Altai Highlands. $7^{\text {th }}-8^{\text {th }}$ century

Kubarev 2005

2 - Kal'džin 8, barrow 1. The Altai Highlands. $9^{\text {th }}-10^{\text {th }}$ century. Reconstruction

Molodin \& al. 2003

This saddle had low-level semi-circular arches, and their shape is similar to that of the soft saddle of the Pazyryk culture of the fifth to third centuries BCE (Kljaštornyj \& Savinov 2005, p. 189). The front arch was placed almost upright, and the rear arch receded significantly. This construction allowed the rider greater movement, while his seat was still firm. One can see a semi-circular protrusion on the lower end of the bar (fig. 3: 1). The arches and bars of this saddle were joined in a flexible way with narrow 
leather strips drawn through special apertures. This construction afforded the saddle stretch and durability, qualities that were important for the nomadic lifestyle.

There was a small gap between the upper edges of the bars. This originated in the soft saddle, which consisted of two leather pads connected by a leather strap. This gap was left in order to prevent friction of the saddle on the horse's spine. It was unavoidable in the construction of the soft saddle in order not to harm the animal's back, and in the wooden saddle-tree it remained as was, even though the firm construction would have made it possible to prevent contact between the saddle and the spine without such a gap.

Based on the representations, one can examine the saddle accessories that were used with the Old Turkic saddle. The stirrup leathers were attached to the lower ends of the front arch, as with the Koguryŏ saddle: so flaps were absent. The short blanket had a trapezoid shape, which also has parallels in the Pazyryk culture.

Thus, the Old Turkic epoch (the second half of the first millennium CE) shaped the nomadic saddle and its accessories (fig. 3: 1, 2), and later it underwent only minor exterior changes, while its basic design remained the same.

Archaeological findings show that these two saddle types (the Koguryo and the old Turkic) coexisted and experienced reciprocal influences. Thus, in the middle of the second millennium the arches of the old Turkic saddle became higher and more massive and were used as a kind of armor to protect the lower part of the rider's body. The semi-circular protrusion at the lower edge of the bar gradually fell out of use (fig. 4: 1). The rear arch of the Koguryŏ saddle in its turn receded, giving the rider greater freedom in his movements, and the various parts of the saddle were now bound with leather strips, which made the saddle more flexible (fig. 4: 2; Uray-Köhalmi 1968, fig. 8).

Fig. 4. The saddles of the early part of the second millennium CE
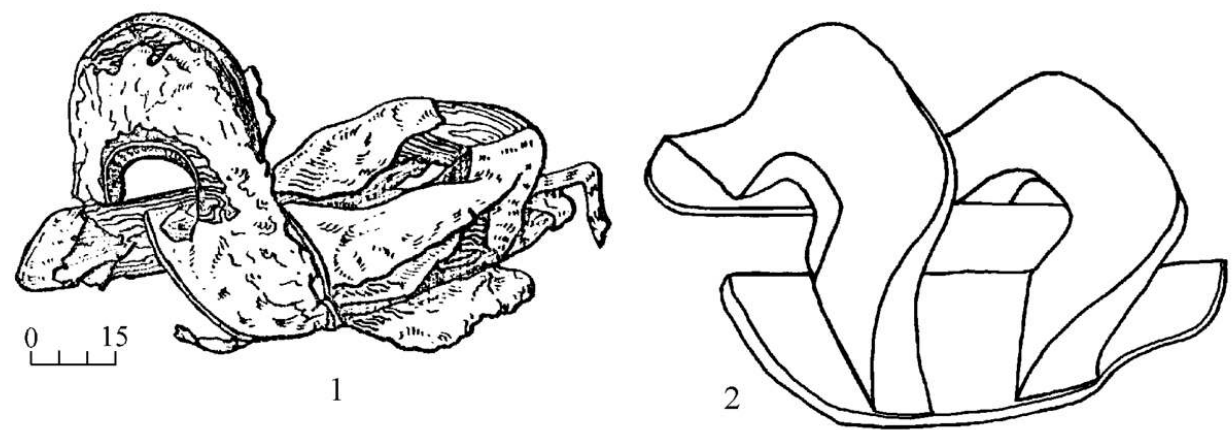

1 - the Western type. Uzun-Haya, grotto $1.11^{\text {th }}-13^{\text {th }}$ century. The Minusinsk Depression Kyzlasov 1983

2 - the Northern type. Časovennaja Gora, burial 3. $12^{\text {th }}-13^{\text {th }}$ century. Southern part of the Krasnojarsk Kraj

Savinov 1977 


\section{Horse equipment of the Late Middle Ages}

From the beginning of the second millennium CE a new subtype of saddle emerged in Southern Siberia: one with triangular arches. It is represented by metallic overlays on arches found in accidental finds in the Minusinsk Depression and funerary complexes in Tuva (fig. 5). In the eleventh and twelfth centuries the local population cremated their dead (which is corroborated by Chinese sources as a feature of the Turkic tribes). Most commonly it is explained as being a practice of the Yenisei Kyrgyz or being due to their cultural influence. Unfortunately this funerary custom did not allow for any wooden parts of a saddle to be preserved, and so its construction remains unknown. Similarly we do not possess any information on the saddle accessories. The comparison with the later ethnographic materials suggests that an oblong blanket and flaps were used.

Fig. 5. Metal overlays of saddles with triangular arch, $11^{\text {th }}-13^{\text {th }}$ century

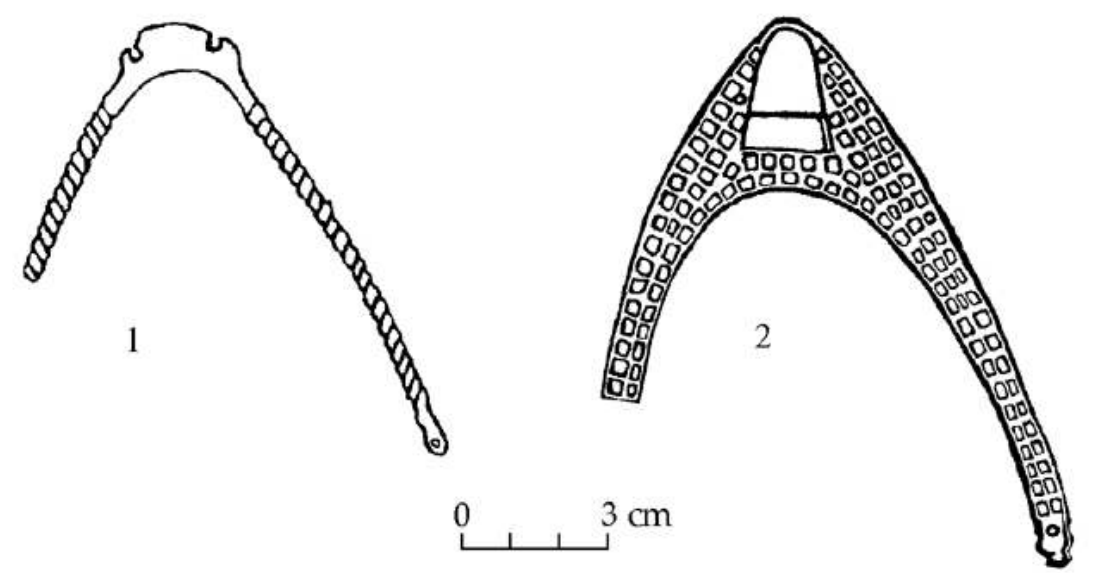

1 - accidental find in the Minusinsk Depression

2 - Demir Sug. Tuva

Savinov 1977

Saddles with triangular arches are unknown in the Altai. However, the Tuvan funerary monuments of the second half of the second millennium contain only this saddle type (D'jakonova 1975, p. 34-38). Most probably its origins were associated with the early Mongols (it appeared in Southern Siberia in the period of their early political activity), since it is typical of the regions that were under the control of the Dzungar khanate (1635-1758), which was established by the Mongol-speaking tribal union of the Oirats.

As can be seen from the above information, archaeological data show that in the middle of the second millennium CE three main types of riding saddle existed.

The Western Type is a modernized old Turkic saddle with a short blanket and no flaps; its origins and evolution are mainly associated with the Altai region.

The Northern Type is based on the Koguryŏ saddle. Although its origins are rooted in Northern Central Asia and its evolution was influenced by the old Turkic saddle, it is preserved in the archaic shape only in the culture of the Yakuts, the northernmost horse-breeders. The numerous indications on the ethnic origins of the Yakuts clearly 
show that after their ancestors left the main Turkic-speaking area they preserved certain archaic elements of their culture, which can be traced back to the Late Middle Ages.

The Southern (Mongol) Type is based on a saddle with triangular arches.

\section{Horse equipment of ethnographic modernity (late nineteenth to early twentieth century)}

31 At the turn of the twentieth century the riding horse remained the main means of transport among nomads and horse equipment was a rather enduring element of their traditional culture. Tack used for weddings is particularly interesting since the items related to the festival and other ceremonial sides of life are characterized by a certain degree of persistence. Such tack is widely represented in museum collections, since the riding horse with its festive equipment was an unavoidable part of the bride's dowry of all the cattle-breeding nomadic peoples of Siberia and Central Asia.

Nowadays, despite the development of modern vehicles and the construction of motorways, the important role of horseback riding is still preserved in certain parts of Tuva and The Altai Highlands. The traditional wooden saddles have practically fallen out of use, and although they can sometimes be seen at festivals, in everyday life they have been completely replaced by standard factory-built ones with arches made of curved metal tubing (fig. 15). Other parts of tack prepared according to traditional technologies are even rarer.

The ethnographic data enable us to verify the conclusions drawn on the basis of archaeological materials. When examining the equipment of a riding horse, one can single out the following elements as the most informative ones:

- Saddle construction: the shape of its front arch, the location of the aperture for the stirrup

leather, presence or absence of a gap between the bars;

- Saddle ornamentation: the shape and location of metal decorative overlay;

- Decoration of the harness buckles: whether they have decorative metal overlay or are decorated by open-ended rings.

- Saddle accessories: presence or absence of flaps, cover of the horse's croup, saddle decorations, shape of the blanket.

None of these elements is ethnically determinative and only a combination of these features in one style can be regarded as one of the most prominent indicators of the culture of a given people. Various combinations of the above-mentioned features allow us to determine three ethno-cultural styles, which generally agree with the archaeological ones (see map). 


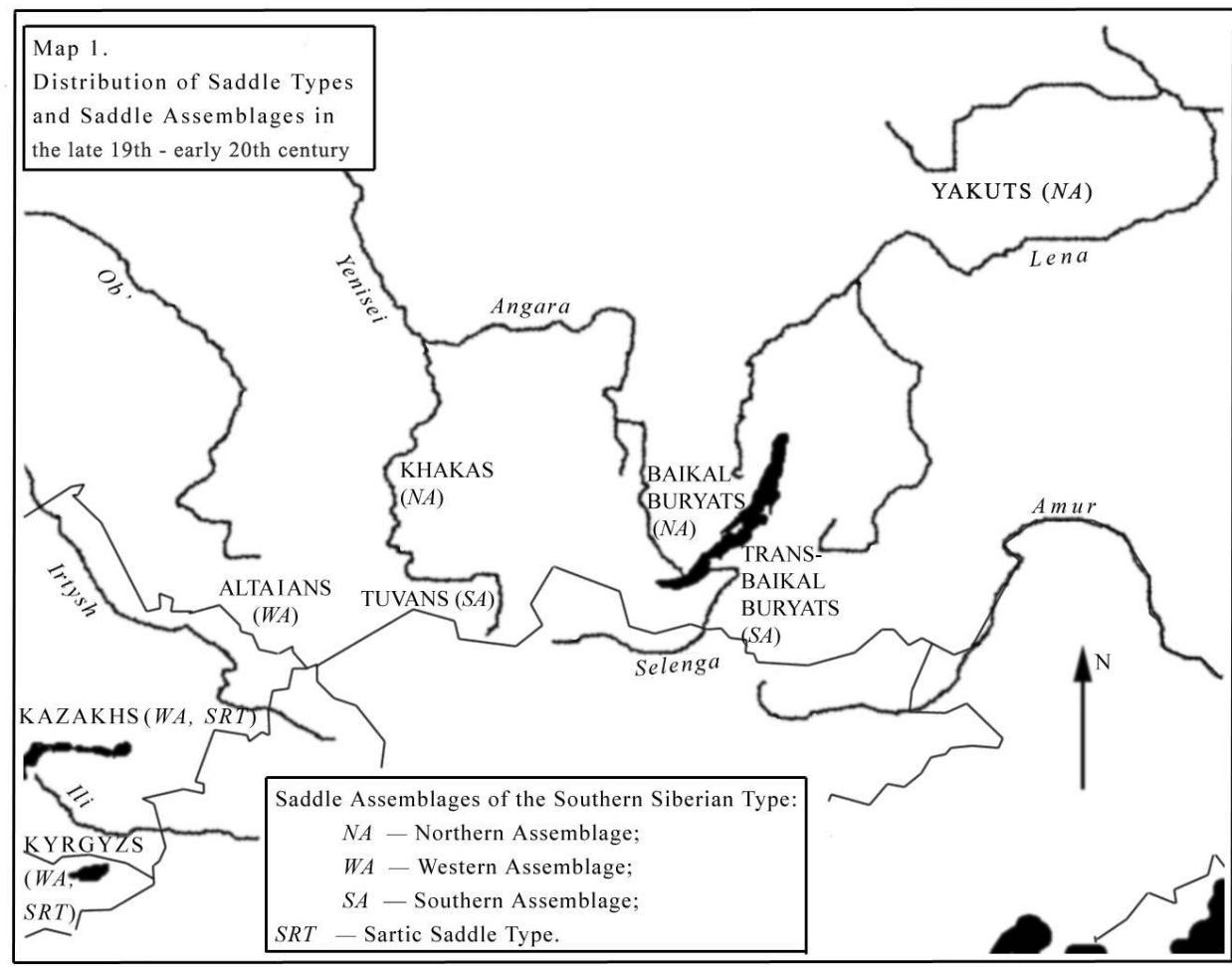

\section{The Northern Style}

The Northern style includes the equipment of the Yakuts, Khakass and Baikal Buryats. It is based on a massive saddle with bars around $55 \mathrm{~cm}^{\text {long }}{ }^{3}$.

The culture of the Yakuts preserves its most archaic variant with orthogonal arches, attachment of stirrup leathers to the base of the front arch and consequently an absence of flaps, and the blanket made of two pieces of cloth attached with leather straps under the saddle (fig. 6, $7^{4}$ ). These elements are a heritage of the Koguryŏ saddle (fig. 1, 6). The Yakuts also use a saddle with the semicircular front arch; its origins probably go back to the old Turkic saddle. 
Fig. 6. The Northern type

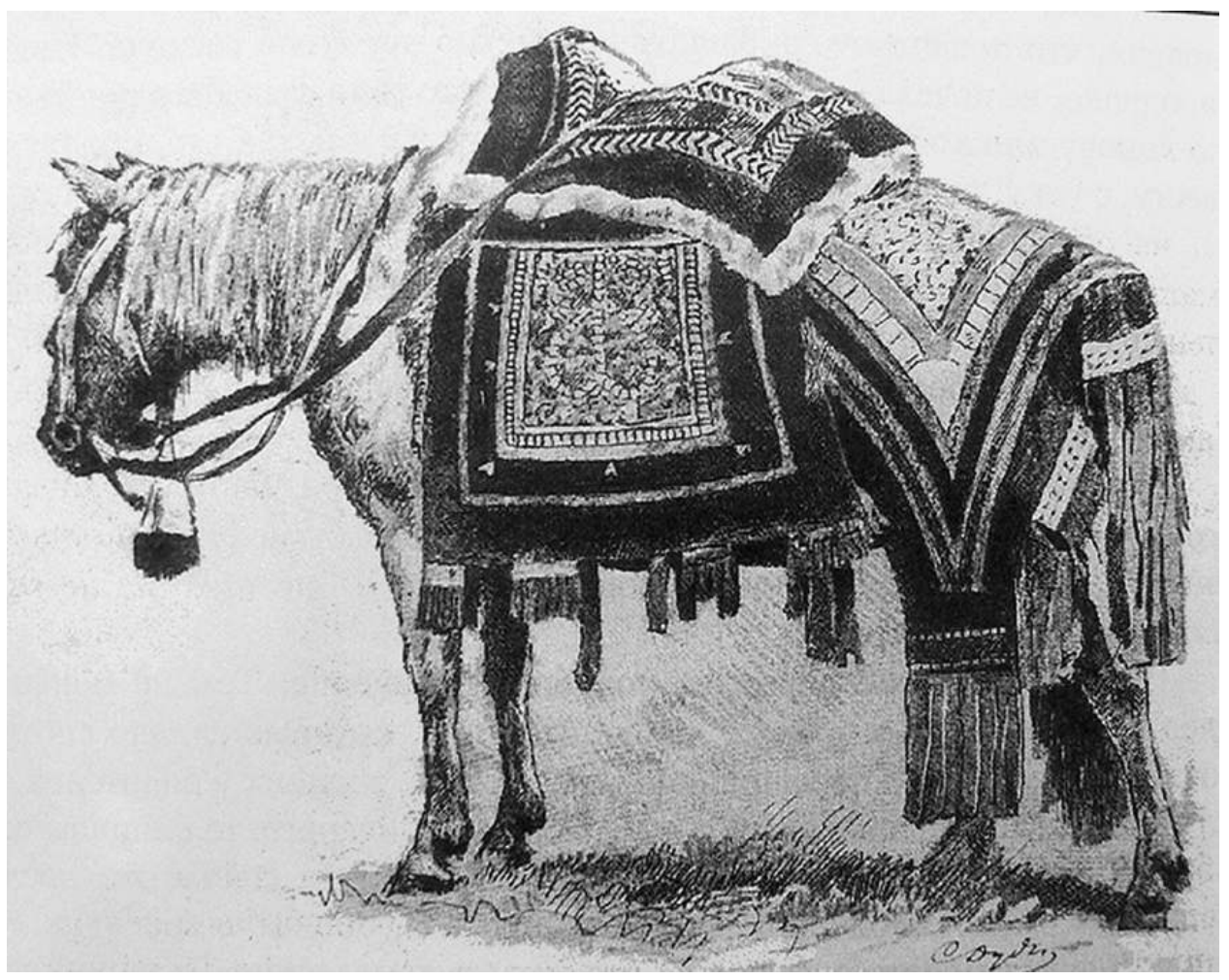

A horse tacked decoratively for a wedding. Yakuts, late $19^{\text {th }}$-early $20^{\text {th }}$ century Seroševskij [1896] 1993 


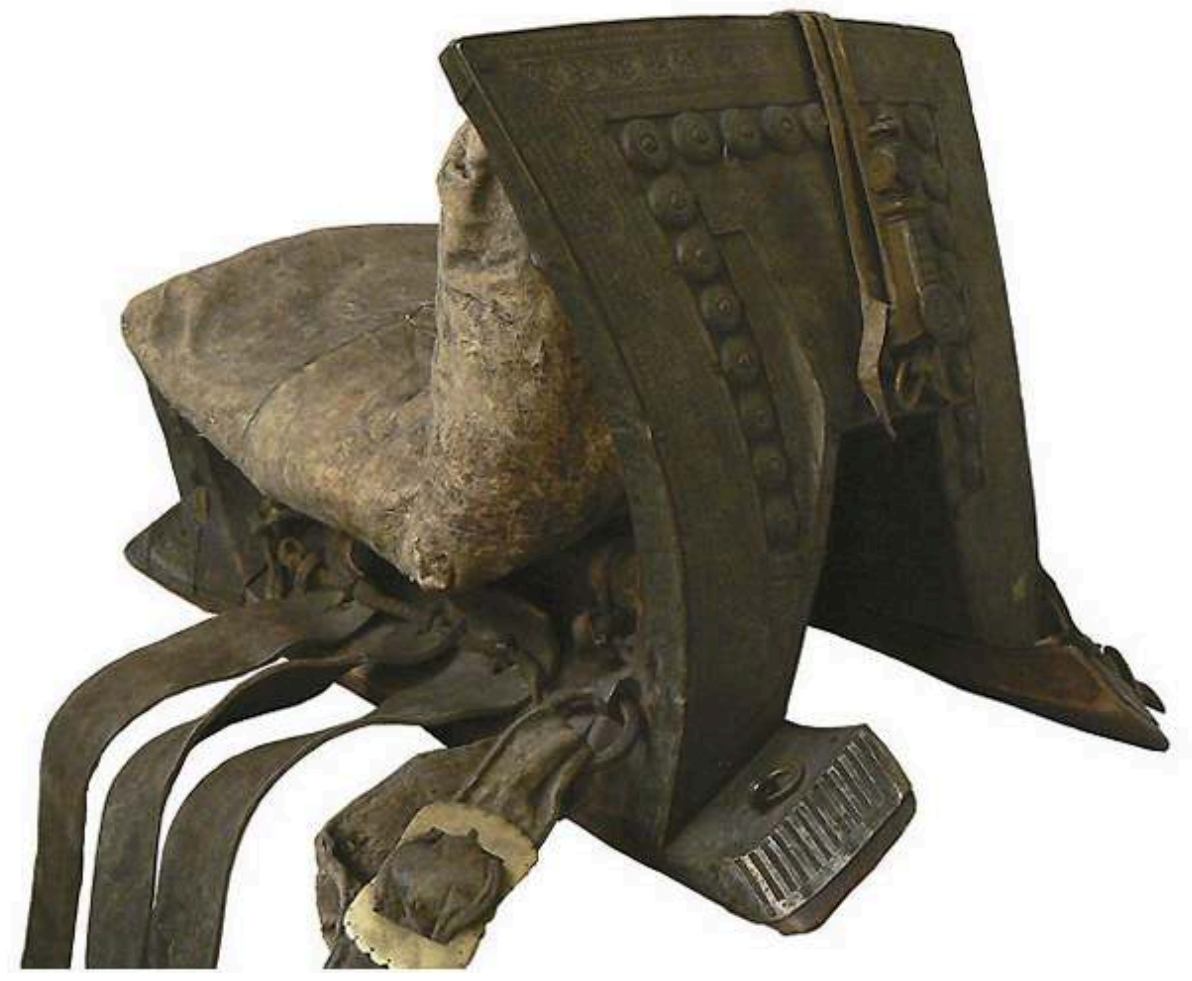

Lady's wedding saddle. Yakuts, late $19^{\text {th }}$-early $20^{\text {th }}$ century.

Collection of the Russian Ethnographic Museum.

Photo by the author

The tack of the Yakuts and Khakass also includes a cover for the horse's croup which is tied to the back of the saddle and is unknown in the culture of other peoples (fig. 6, 8). There are several terms for this cover in the Yakut language: čapparaak, čappyraak, čapraak, čamparaak, while a blanket (Russ. čeprak) is called kyčym (Pekarskij [1907-1930] 1959, col. 1454, 3574). The Khakass language has similar terms, respectively čaprah and kičìm (Butanaev 1999, p. 45, 210). This similarity between the elements of horse equipment and the related terms indicates the close contact between the ancestors of the Yakuts and Khakass in the past. 
Fig. 8. The Northern type

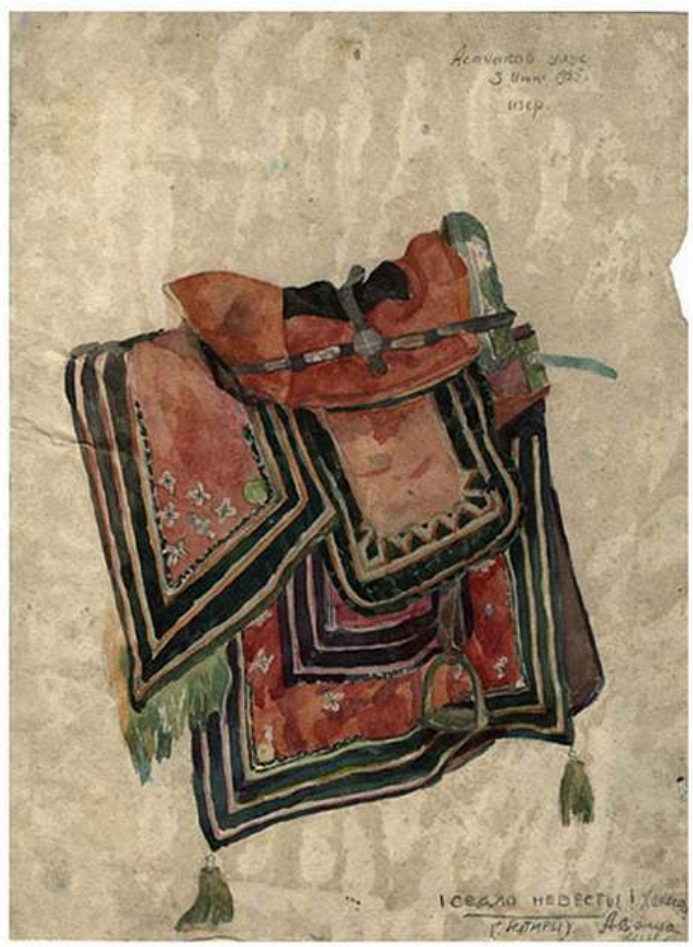

Bride's saddle. Khakass.

Drawn by A. V. Voščakin, 1925 
Fig. 9. The Northern type

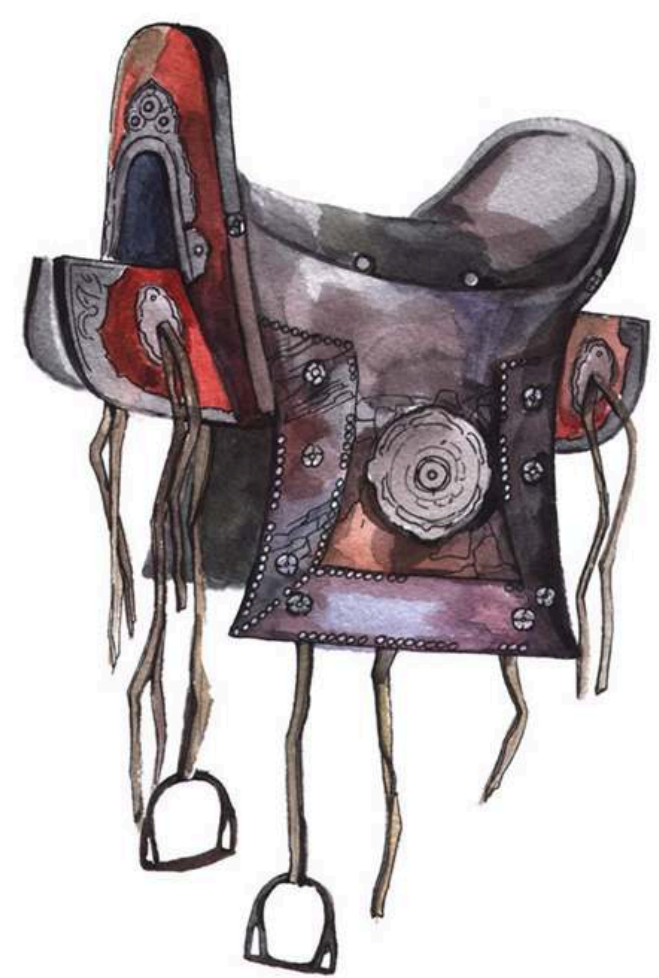

Man's saddle. Buryats, late $19^{\text {th }}$ - early $20^{\text {th }}$ century

Collection of the Russian Ethnographic Museum.

Drawn by U. A. Kulogaševa

The front arches of the saddles of the Khakass and Baikal Buryats (fig. 9) are close in shape. Another similarity of the tack of these two peoples is the existence of a special decoration for the festive lady's saddle: tator among the Khakass and ag-tabša among the Buryats (fig. 10). These decorations constitute a frame made of leather strips and ornamented with metal plaques. They are placed above the saddle-pad. The origin of this element is unexplained. It is probably a vestige of some element of the saddle accessories of the medieval rider with its practical function having fallen into oblivion. The existence of this specific decoration only among these two peoples indicates the close ethno-cultural links between their ancestors. 
Fig. 10. The Northern type

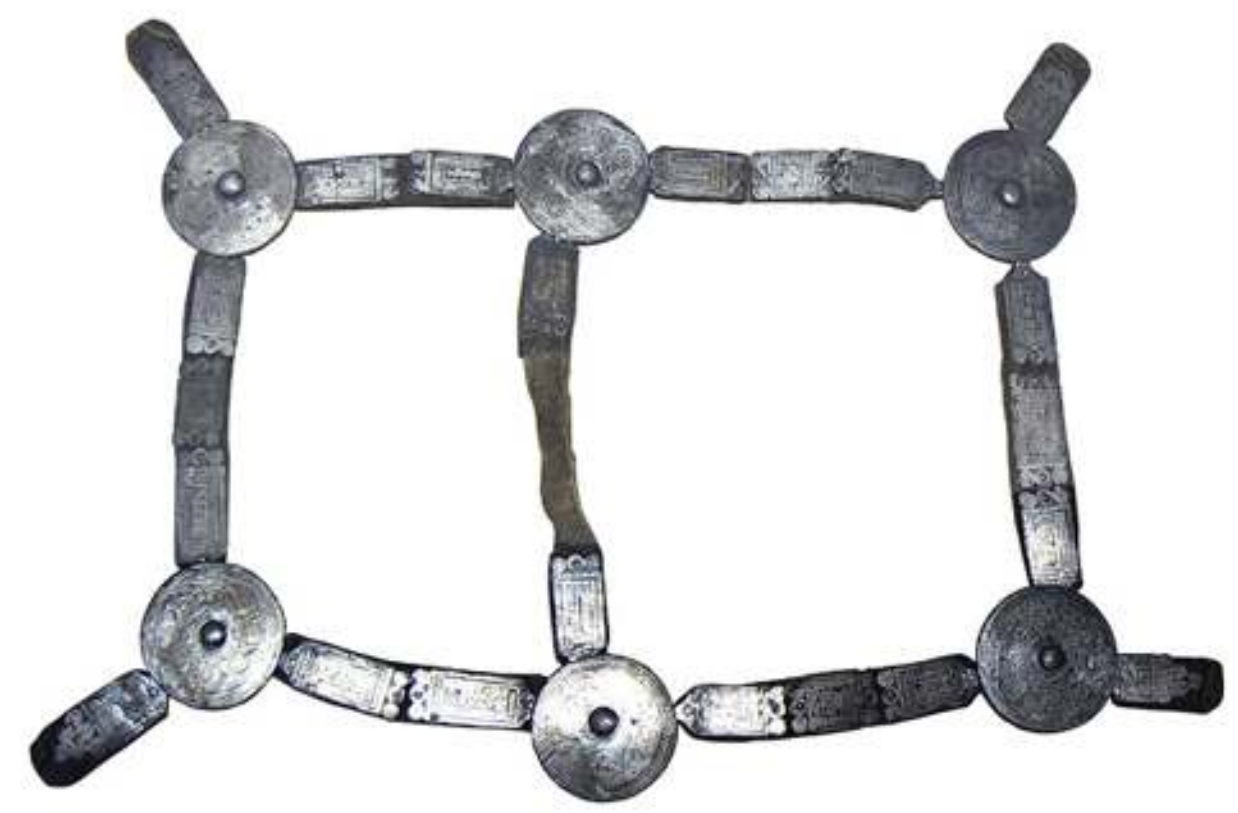

Ag-tabša - decoration of a lady's saddle. Buryats, early $20^{\text {th }}$ century Collection of the Russian Ethnographic Museum.

Photo by the author

\section{The Western Style}

The Western style includes the Altaians, Kazakhs and Kyrgyz. It is characterized by a saddle of moderate size with the bars around $50 \mathrm{~cm}$ long, mostly with wide, semicircular arches and a gap between the upper edges of the bars (fig. 12). The aperture for the stirrup leather is located in the front part of the tree, so flaps are usually absent. The Western style mostly contains a short trapezoid blanket with its lower ends above the level of the stirrup (fig. 11), while in the Northern and Southern styles it goes below the stirrups (fig. 8). All these elements are most likely a heritage of the old Turkic saddle (more detailed examination in Tkačenko 2008, p. 78-82). The wedding and festive lady's saddles among the Kazakhs and the Altaians were covered with a special coverlet, called bütelgen (Alt.) or at-türman (Kaz). Such a coverlet is seen only in the Western style and is alien to Northern and Southern ones. 
Fig. 11. The Western type

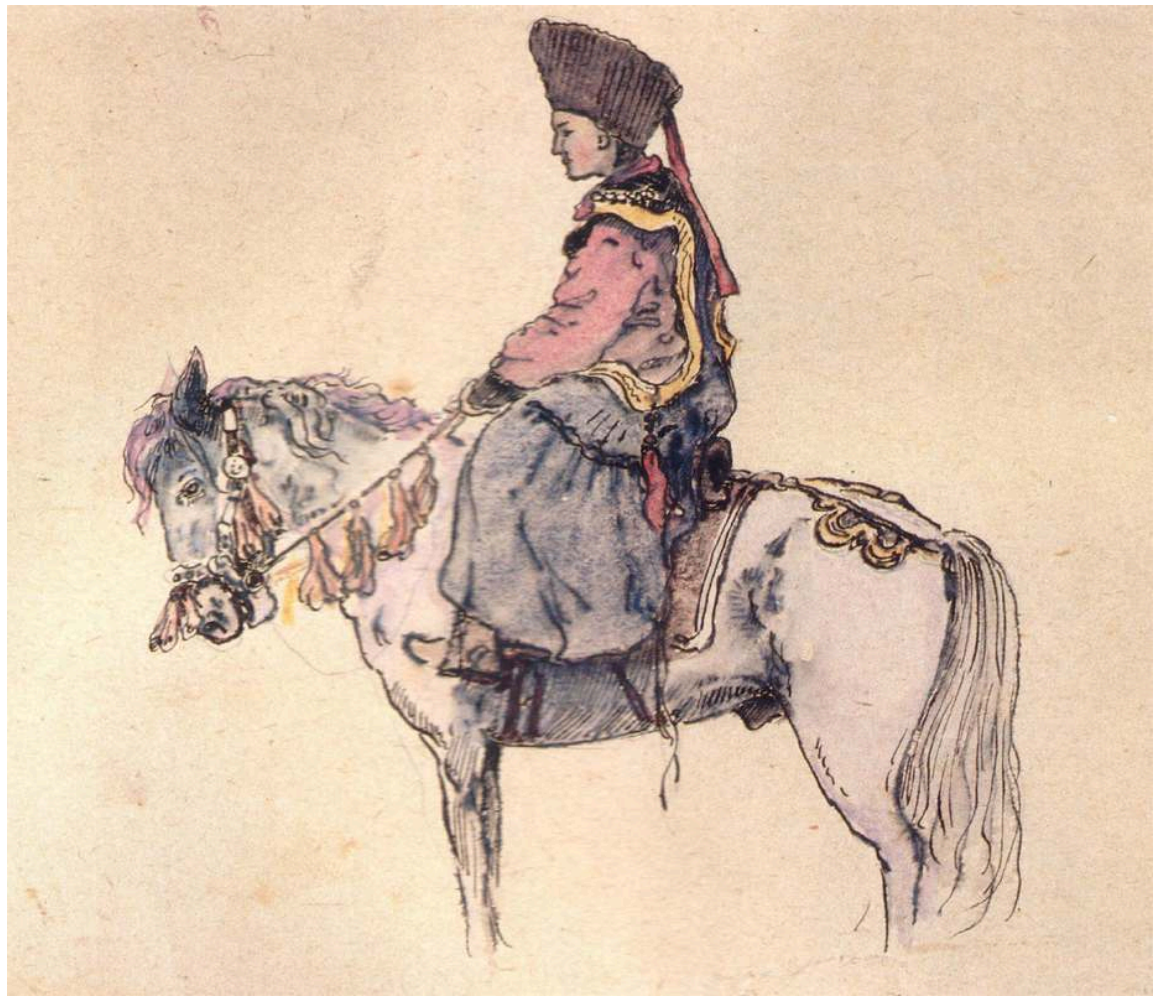

A woman riding on horseback.

Altaians, early $20^{\text {th }}$ century

Drawn by G. I. Čoros-Gurkin 

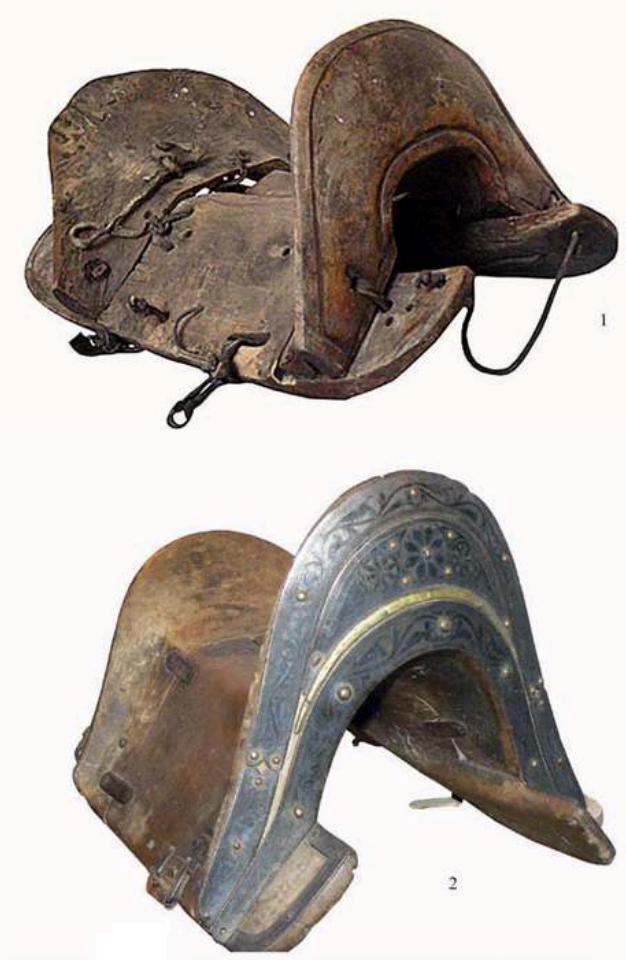

1 - tree of a lady's saddle. Altaians, mid-20 th century

2 - tree of a saddle. Kyrgyz, late $19^{\text {th }}$ - early $20^{\text {th }}$ century

Collection of the Russian Ethnographic Museum

Photo by the author

One can note that the saddle styles of the Kazakhs and Kyrgyz demonstrate a far greater variation than those of the Altaians ${ }^{5}$. In the southern regions of Kyrgyzstan and Kazakhstan the saddle of the Sartic type with the multipartite compound tree (or Andijan type, II in our typology) was widespread. Earlier, these saddles were more commonly used among women, since they were considered to be easier and more comfortable.

In Western and North-western Kazakhstan, saddles of the transitional type (type III in our typology) were used. Most probably this saddle type (with a quadripartite tree and a figured pommel on the front arch) is the result of a symbiosis between the Southern Siberian and Sartic types, which took place in the period of ethnographic modernity, since we do not find them in the archaeological materials of the Late Middle Ages. This question, however, needs additional research, which goes beyond the limits of the present article.

The saddles of the Southern Siberian type (fig. 12: 2) were also widely used among the Kyrgyz and Kazakhs, as well as the saddle accessories that have close parallels in the culture of the Altaians. This fact bears witness to the close contact between the ancestors of these peoples.

Both the Northern and the Western styles are characterized by wide leather straps (fig. $8,10,11$ ) and a decorative style where the metal covers the whole surface, not only the afore-mentioned straps, but the outer surface of the saddle arch as well. This fact attests to the common roots and similar ways of forming this equipment. 


\section{The Southern Style}

The basis of the style of the Tuvans, Transbaikal Buryats and in part the Telengits of the Eastern Altai is represented by a smaller saddle (fig. 14) with bars around $45 \mathrm{~cm}$, rarely up to $50 \mathrm{~cm}$ long, triangular arches and the upper edges of the bars adjoining one another (without a gap between them). The origins of this type of saddle have barely been studied. Most probably it originates from the same territory where the Koguryŏ saddle appeared one thousand years earlier (which was also devoid of a gap between the upper edges of the bars).

Fig. 13. The Southern type

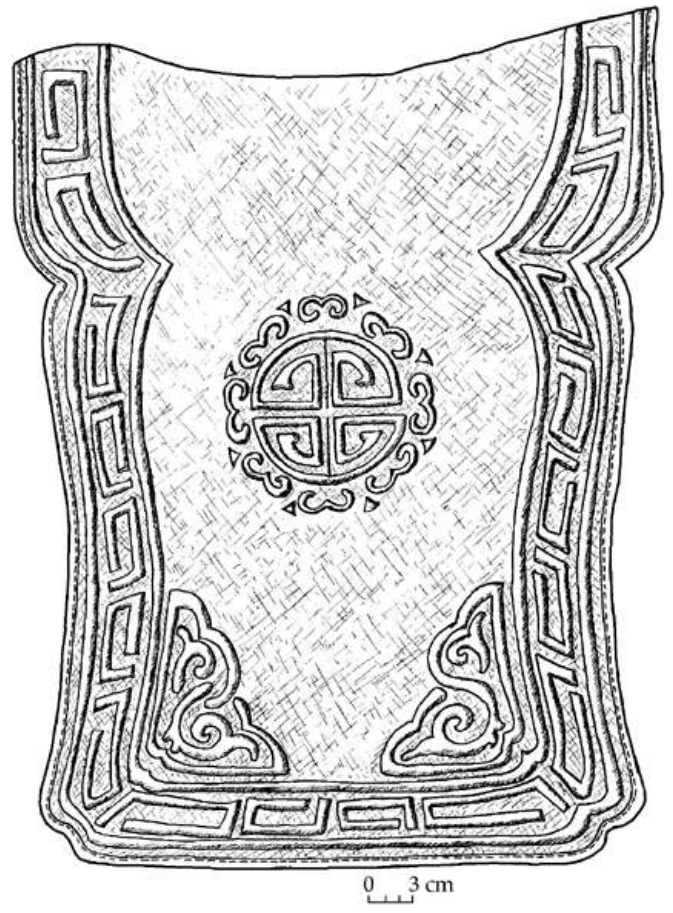

Fragment of a blanket. Tuvans, late $19^{\text {th }}$ - early $20^{\text {th }}$ century Collection of the Russian Ethnographic Museum

Sketch by the author 


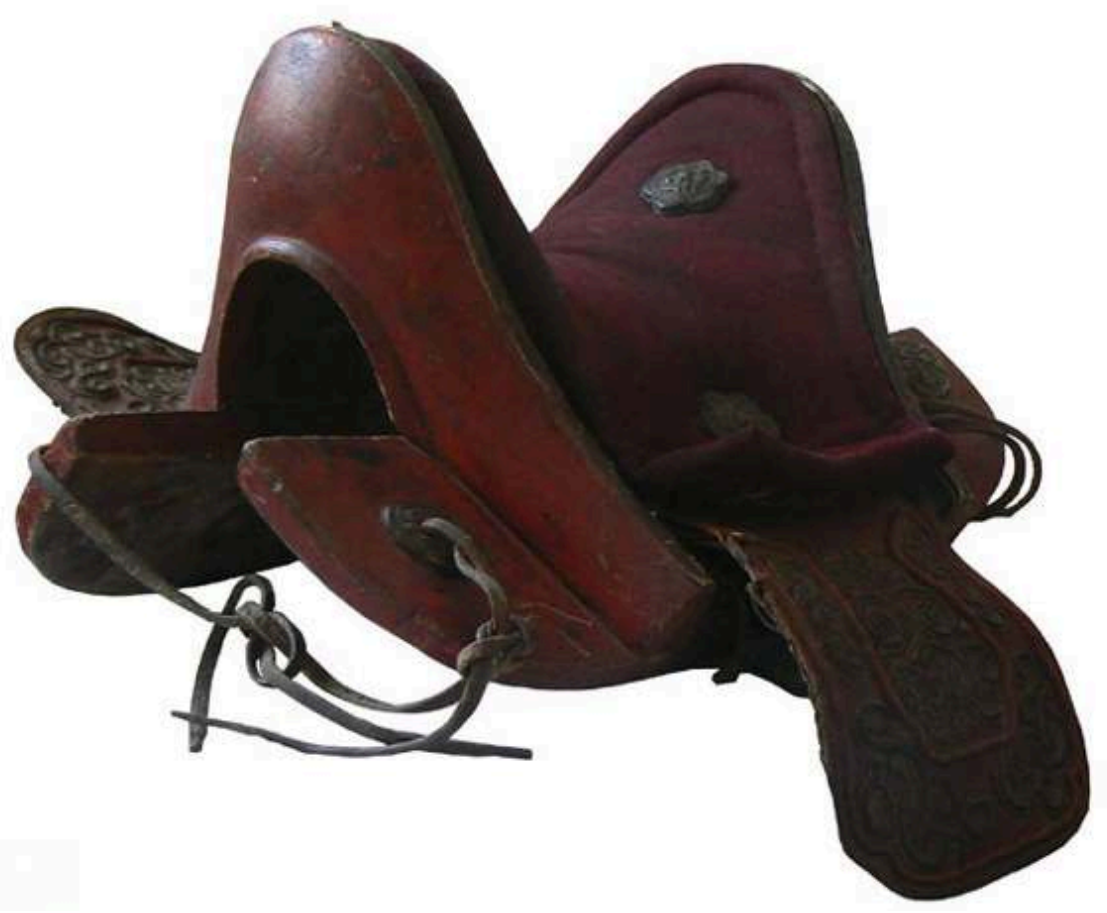

Saddle. Tuvans, late $19^{\text {th }}$ century

Collection of the Russian Ethnographic Museum

Photo by the author

The history of the development of this saddle is bound to the Mongols, so in literature it is called a Mongol-Tuvan saddle (Vajnštejn 1991, p. 211) ${ }^{6}$. The aperture for the stirrup leather is located in the middle part of the tree, and the leather passed beneath the rider's thigh and was always covered with a flap. The blanket has a very peculiar shape: it is oblong, and narrow at its lower part, with rounded corners (fig. 13). The saddle accessories are made of leather and decorated with embossment.

The harness and bridle features are made of narrow double leather straps, which are threaded through tricuspid eyelets of plaques or braided with one another (fig. 15). The straps are reinforced (and decorated) with metal open-ended rings.

The decorative style of this equipment is characterized by metal elements only partially covering the surface. 
Fig. 15. The Southern type

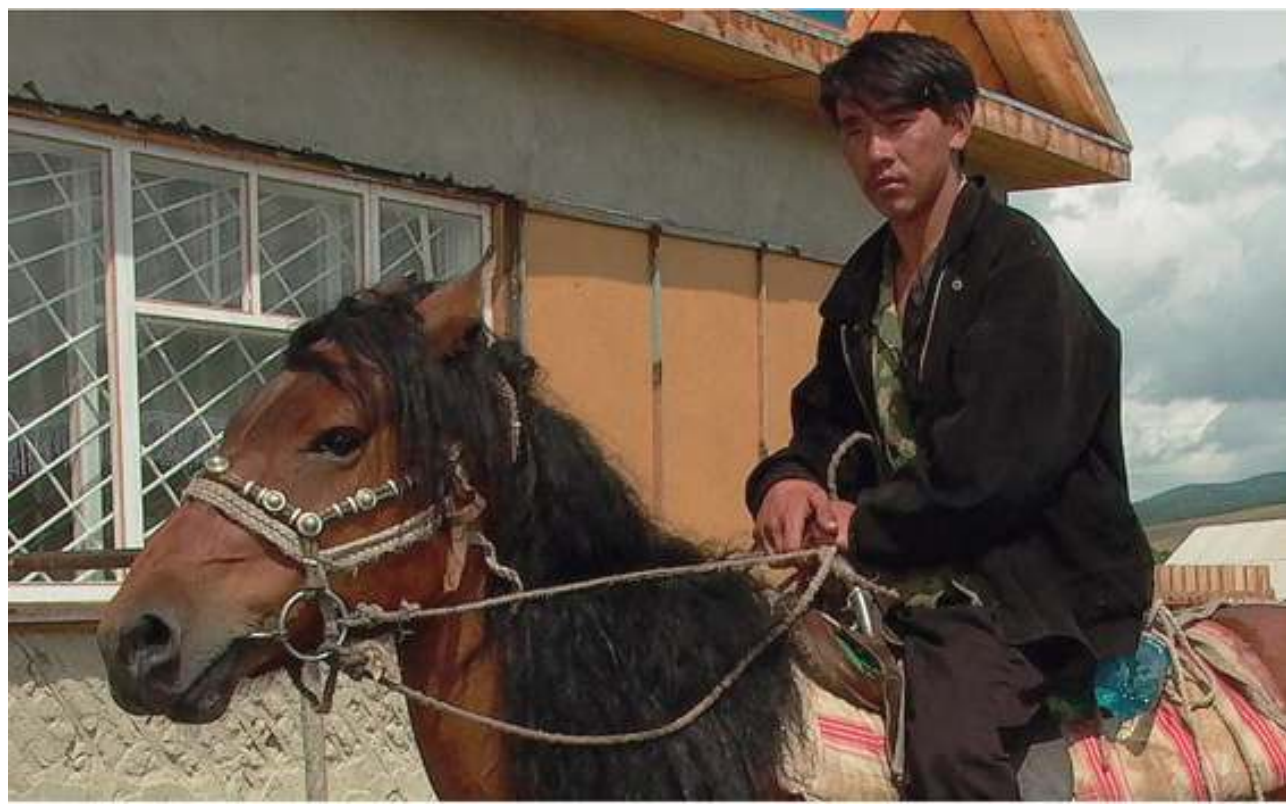

A man riding on horseback. Altaians (Telengit)

Altai Republic, Ulagan region, Balyktujul

Photo by O. P. Ignat'eva 2006

\section{Conclusions}


to the Kurumchi archaeological culture which flourished in the Baikal region from the sixth to tenth century. From the ninth to the thirteenth century the Qïrqïz Kaghanate controlled Southern Siberia, and in different periods its territory included the Minusinsk Depression (Khakassia), Tuva, North-Western Mongolia and part of Cisbaikalia. The Northern type of horse equipment prevailed among this population in the late nineteenth-early twentieth century.

The territories of the Western type were under the influence the Kimäk State (from the ninth to eleventh century) and their Qïpčaq heirs (from the eleventh to thirteenth century). In the post-Mongol period the territory of Altai was considered the eastern periphery of the circle of influence of the Nogay horde and the Üzbek khanate (fifteenth-seventeenth centuries), and this fact explains the close cultural contacts between the ethnic groups that later became the Altaians, Kazakhs and Kyrgyz.

The shaping of the Southern type took place under the strong influence of the Mongols. The territory of Transbaikalia was inhabited by various Mongol-speaking groups almost until the end of the eighteenth century; even now it is still partially inhabited by Buryats. Tuva for a long time, particularly between the sixteenth and the first half of the eighteenth century was a part of the Mongol state of Altan-khans and later the Dzungar khanate, and this fact did not fail to be closely mirrored in the character of horse equipment.

\section{BIBLIOGRAPHY}

Azbelev, P. P.

2008 Stremena i sklepy taštykskoj kul'tury [Stirrups and burial chambers of the Tashtyq culture], Issledovanija arheologičeskih pamjatnikov epohi srednevekov'ja [Research of archeological monuments of the Medieval Epoch] (St.-Peterburg, Nestor-Istoria), pp. 56-68.

Butanaev, V. Ja.

1999 Hakassko-russkij istoriko-ètnografičeskij slovar' [Khakass-Russian ethnographic dictionary]

(Abakan, Hakassija), 240 p.

Čoros-Gurkin, G. I.

sine anno Katalog vystavki k 125-letuju so dnja roždenija hudožnika [A catalogue of the exhibition dedicated to the $125^{\text {th }}$ anniversary of the birth of the painter G. Čoros-Gurkin] (Gorno-Altajsk, Gorno-Altajskij respublikanskij kraevedčeskij muzej), 56 p.

D'jakonova, V. P.

1975 Pogrebal'nyj obrjad tuvincev kak istoriko-ètnografičeskij istočnik [The funerary customs of Tuvans as a historico-ethnographical source] (Leningrad, Nauka), $164 \mathrm{p}$.

Džarylgasinova, R. ̌̌.

1972 Drevnie kogurëscy. K ètničeskoj istorii korejcev [The ancient Koguryŏ peoples. On the ethnic history of the Koreans] (Moskva, Nauka), 200 p. 
Gavrilova, A. A.

1965 Mogil'nik Kudyrgè kak istočnik po istorii altajskih plemen [Kudyrgè Burial as a source on the history of Altaic tribes] (Moskva, Nauka), 145 p.

Grač, V. A.

1982 Srednevekovye vpusknye pogrebenija kurgana-hrama Ulug Horum v Južnoj Tuve [Medieval secondary burials from the kurgan-temple Ulug Horum in Southern Tuva], Arheologija Severnoj Azii [Archaeology of Northern Asia] (Novosibirsk, Nauka), pp. 156-168.

Kljaštornyj, S. G. \& D. G. Savinov

2005 Stepnye imperii drevnej Evrazii [The steppe empires of Ancient Eurasia] (St.-Peterburg, SPg gosudarstvennyj universitet), $347 \mathrm{p}$.

Krjukov, M. V., V. V. Maljavin \& M. V. Sofronov

1984 Kitajskij ètnos $v$ srednie veka (VII-XIII vv.) [The Chinese ethnos in Medieval times $\left(7^{\text {th }}-13^{\text {th }}\right.$ centuries)] (Moskva, Nauka), $336 \mathrm{p}$.

Kubarev, G. V.

2005 Kul'tura drevnih turok Altaja (po materialam pogrebal'nyh pamjatnikov) [The culture of the ancient Turks of Altai (on the materials of the funerary monuments)] (Novosibirsk, Institut arheologii i ètnografii Sibirskogo otdelenija RAN), 400 p.

Kyzlasov, I. L.

1983 Askizskaja kul'tura Južnoj Sibiri X-XIV vv. [The Askiz culture of Southern Siberia, $10^{\text {th }}-14^{\text {th }}$ centuries] (Moskva, Nauka), 128 p.

Molodin, V. I., A. V. Novikov \& A. I. Solov'ev

2003 Pogrebal'nye kompleksy drevnetjurkskogo mogil'nika Kal'džin-8 (nekotorye tehnologičeskie i ètnokul'turnye rekonstrukcii) [The funerary assemblages of the Old Turkic burial Kal'džin-8 (some technological and ethnocultural reconstructions)] Arheologia, ètnografija $i$ antropologija Evrazii [Archaeology, ethnography and anthropology of Eurasia], 2 (14), pp. 71-86.

Pekarskij, E. K.

[1907-1930] 1959 Slovar' jakutskogo jazyka [Dictionary of the Yakut language] (Leningrad, Nauka), 3 t., $3858 \mathrm{p}$.

Savinov, D. G.

1977 Iz istorii ubranstva verhovogo konja u narodov Južnoj Sibiri (II tysjačeletie n.e.) [On the history of the decoration of the riding horse among the peoples of Southern Siberia $\left(2^{\text {nd }}\right.$ millennium (E)], Sovetskaja ètnografija [Soviet Ethnography], 1, pp. 31-48.

1984 Narody Južnoj Sibiri v drevnetjurkskuju epohu [The peoples of Southern Siberia in the Old Turkic epoch] (Leningrad, Leningradskij gosudarstvennyj universitet), 175 p.

Seroševskij, V. L.

[1896] 1993 Jakuty. Opyt ètnografičeskogo issledovanija [The Jakuts. An attempt of an ethnographical description] (Moskva, Rossijskaja političeskaja ènciklopedija), 736 p.

Tkačenko, I. D.

2008 Sedel'nyj kompleks altajcev (istorija formirovanija i razvitija) [Riding tack of the Altaians (the history of its creation and development)] Ètnografija Altaja i sopredel'nyh territorij [Ethnography of the Altai and neighboring territories],7 (Barnaul, Barnaul'skij gosudarstvennyj pedagogičeskij universitet), pp. 78-82.

2009 Snarjaženie verhovogo konja kočevnikov Sibiri i Central'noj Azii (opyt istoriko-ètnografičeskogo issledovanija) [The equipment of the riding horse of the nomads of Siberia and Central Asia (an attempt of historico-ethnographic research)]. Dissertation presented for the degree of a 
candidate of historical sciences, supervised by Dr. Larisa R. Pavlinskaja. The defense took place in May 2009 in the Museum of anthropology and ethnography named after Peter the Great at the Russian Academy of Sciences (Kunstkamera), St.-Petersburg.

Uray-Köhalmi, K.

1968 Two saddles finds from Western Mongolia, Acta Archaeologica, t. 20, fasc. 4, pp. 347-358.

Vajnštejn, S. I.

1966 Nekotorye voprosy istorii drevnetjurkskoj kul'tury (v svjazi s arheologičeskimi issledovanijami v Tuve) [Some questions of the history of the old Turkic culture (as related to recent archaeological research in Tuva], Sovetskaja ètnografija [Soviet ethnography],3, pp. 60-81. 1991 Mir kočevnikov Centra Azii [The world of the nomads in the Center of Asia] (Moskva, Nauka), 296 p.

In the editor's notes

Aubin, F.

1986a L'art du cheval en Mongolie, Production pastorale et société, 19, pp. 129-149.

1986b Le folklore comme mass media. L'exemple de la selle chez les Mongols,

L'Ethnographie,LXXXII, 98-99, pp. 119-144.

Digard, J. P.

2004 Une histoire du cheval. Art, techniques, société (Arles, Actes Sud), 232 p.

Ferret, C.

2009 Une civilisation du cheval. Les usages de l'équidé, de la steppe à la taïga (Paris, Belin), 350 p.

Uray-Kühalmi, C.

1974 La périodisation de l'histoire des armements des nomades des steppes. De l'époque des Cimmériens à la chute de l’Empire mandchou, Études mongoles, 5, pp. 145-155.

\section{NOTES}

1. The terms ethnographic period or ethnographic modernity cover the traditional people's culture of the late nineteenth-early twentieth century, i.e. the earliest period studied by ethnographers in sufficient detail. The Russian historiography also includes here fragmentary ethnographic data of the eighteenth and nineteenth centuries as well as those elements of traditional culture which have remained alive into the early twenty-first century.

2. For another attempt of classification of Inner Asian saddles see Uray-Kühalmi 1974 and Digard 2004, p. 105 (editor's note).

3. For a description of the two main forms of Yakut saddles, see Ferret 2009 (editor's note).

4. Henceforth, all the items from the collection of the Russian Ethnographic Museum are published with kind permission of the administration of the Museum.

5. On the various types of Kazakhs saddles, see Ferret 2009 (editor's note).

6. On the style of the Mongol saddle, see Aubin 1986a, p. 131. On the recent cult of the saddle as a luxury object among Mongols, see Aubin 1986b (editor's note). 


\section{ABSTRACTS}

The present paper deals with the development of horse tack among the cattle-breeding nomads from the early Turkic period (mid-first millennium CE) up to ethnographic modernity (midtwentieth century) based on the analysis of archaeological and ethnographic data. The materials show that at the beginning of the second millennium CE three main types of tack were in use, and in particular, three types of saddle: the Northern, the Western and the Southern. These types of tack, in somewhat different shapes and a greater variation of forms, were in use in this region up to the early twentieth century. This fact allows us to determine the direction of the ethnogenetic processes and to show the stability of ethno-cultural ties within the societies using the different types of tack.

Sur la base de documents archéologiques et ethnographiques, l'article examine l'évolution du harnais du cheval de selle des peuples pasteurs, depuis l'époque des Turcs anciens (milieu du I ${ }^{\text {er }}$ millénaire) jusqu'à la première moitié $\mathrm{du} \mathrm{xx}^{\mathrm{e}}$ siècle. Au début $\mathrm{du} \mathrm{II}^{\mathrm{e}}$ millénaire, en Sibérie méridionale et en Asie centrale, se sont formés trois types de harnais, et notamment trois types de selles (septentrional, occidental et méridional), qui, avec certaines variations dans leurs formes, se sont conservés jusqu'au début $\mathrm{xx}^{\mathrm{e}}$ siècle.

\section{INDEX}

Geographical index: Sibérie, Asie centrale

Keywords: ethnoarchaeology, horse, harness, saddle

Mots-clés: ethnoarchéologie, cheval, harnais, selle

Subjects: nomadisme, élevage, transport

nomsmotscles Kazakh, Kirghiz, Touva, Khaka, Bouriate, Yakoute, Mongol, Scythe, Turc ancien, Télenguite, Altaïen

\section{AUTHOR}

\section{IRINA DMITRIEVNA TKAČENKO}

Irina Dmitrievna Tkačenko est titulaire d'une thèse de candidat en histoire (2009) et travaille au musée ethnographique de Russie à Saint-Pétersbourg. Elle est l'auteur de plusieurs articles consacrés à la question, parmi lesquels :

Tkačenko, I. D. 2003 Uprjaž i sbruja [Le harnais de selle et de trait], in Sistema naučnogo opisanija muzejnogo predmeta. Klassifikacija, metodika, terminologija. Spravočnik (Sankt- Peterburg, Art, Ljuks), pp. 93-122.

Tkačenko, I. D. 2008 Snarjaženie konja kočevnikov Južnoj Sibiri kak istoriko-ètnografičeskij istočnik [Le harnais du cheval chez les nomades de Sibérie méridionale comme source historicoethnographique], in Drevnie i srednevekovye kočevniki Central'noj Azii (Barnaul, Azbuka), pp. 103-106.

iriser@inbox.ru 